\title{
Enhancing photovoltaic performance of perovskite solar cells with silica
} nanosphere antireflection coatings

Luo, Qi; Deng, Xueshuang; Yu, Meidong ; Zhang, Chenxi; Zhou, Xin; Wang, Zengbo; Chen, Xiaohong; Huang, Sumei

\section{Solar Energy}

DOI:

10.1016/j.solener.2018.04.044

Published: 15/07/2018

Peer reviewed version

Cyswllt i'r cyhoeddiad / Link to publication

Dyfyniad o'r fersiwn a gyhoeddwyd / Citation for published version (APA):

Luo, Q., Deng, X., Yu, M., Zhang, C., Zhou, X., Wang, Z., Chen, X., \& Huang, S. (2018).

Enhancing photovoltaic performance of perovskite solar cells with silica nanosphere antireflection coatings. Solar Energy, 169, 128-135.

https://doi.org/10.1016/j.solener.2018.04.044

\footnotetext{
Hawliau Cyffredinol / General rights

Copyright and moral rights for the publications made accessible in the public portal are retained by the authors and/or other copyright owners and it is a condition of accessing publications that users recognise and abide by the legal requirements associated with these rights.

- Users may download and print one copy of any publication from the public portal for the purpose of private study or research.

- You may not further distribute the material or use it for any profit-making activity or commercial gain

- You may freely distribute the URL identifying the publication in the public portal ?
}

Take down policy

If you believe that this document breaches copyright please contact us providing details, and we will remove access to the work immediately and investigate your claim. 


\title{
Enhancing photovoltaic performance of perovskite solar cells with silica nanosphere antireflection coatings
}

\author{
Qi Luo ${ }^{\mathrm{a}}$, Xueshuang Deng ${ }^{\mathrm{a}}$, Chenxi Zhang ${ }^{\mathrm{a}}$, Meidong Yu ${ }^{\mathrm{a}}$, Xin Zhou ${ }^{\mathrm{a}}$, Zengbo Wang ${ }^{\mathrm{b}}$, \\ Xiaohong Chen ${ }^{\mathrm{a}}$, Sumei Huang ${ }^{\mathrm{a}, *}$ \\ ${ }^{a}$ Engineering Research Center for Nanophotonics \& Advanced Instrument, Ministry of Education, School of Physics and Materials Science, East China Normal University, \\ North Zhongshan Rd. 3663, Shanghai 200062, PR China \\ ${ }^{\mathrm{b}}$ School of Electronic Engineering, Bangor University, Bangor LL57 1UT, UK
}

Keywords:

Perovskite solar cells

Antireflection coating

Spin-coating

Photovoltaics

Low-cost and scalable approach

\begin{abstract}
A B S T R A C T
Organic-inorganic halide perovskite solar cells have enormous potential to impact the existing photovoltaic industry. As realizing higher power conversion efficiency (PCE) of the solar cell is still the most crucial task, a great number of schemes were proposed to minimize the carrier loss by optimizing the electrical properties of the perovskite solar cells (PSCs). Here, we focus on another significant aspect that is to minimize the light loss by using an antireflection coating (ARC) component to gain a high PCE for PSC devices. In our scheme, silica nanosphere based ARCs are employed to $\mathrm{CH}_{3} \mathrm{NH}_{3} \mathrm{PbI}_{3} \mathrm{PSCs}$ for enhancing the device efficiency. SiO ${ }_{2}$ nanosphere based ARCs were grown by spin-coating of an aged silica sol. The microstructure and the thickness of the $\mathrm{SiO}_{2}$ nanosphere based ARC were controlled by changing the spin-coating speed from 400 to $4000 \mathrm{rpm}$. The effect of $\mathrm{SiO}_{2}$ nanosphere based ARCs on the photovoltaic performance of perovskite solar cells is systematically investigated. The optimized $\mathrm{SiO}_{2}$ nanosphere ARC coating on cleaned glass substrate exhibited a maximum transmittance of $96.1 \%$ at $\lambda=550 \mathrm{~nm}$ wavelength, and averagely increased the transmittance by about $3.8 \%$ in a broadband of $400-800 \mathrm{~nm}$. The optimized antireflection coating strongly suppressed broadband and wideangle reflectance in typical PSC solar cells, significantly enhancing the omnidirectional photovoltaic (PV) performance of PSCs. As a result, the power conversion efficiency was improved from $14.81 \%$ for reference device without $\mathrm{SiO}_{2}$ nanospheres to $15.82 \%$ for the PSC device with the optimized ARC. Also, the PV performance of the PSC device with the optimized $\mathrm{SiO}_{2}$ nanosphere ARC revealed less angular dependence for incident light.
\end{abstract}

\section{Introduction}

Increasing energy demand, environmental issues and limited availability of fossil fuels are demanding sustainable and renewable energy resources. Solar photovoltaic (PV) technology provides an ecofriendly and renewable energy route to directly convert photon energy into electricity (Kerr, 2007). After decades of research silicon (Si) solar cells have achieved record device efficiencies above 26\% (Green et al., 2018). Confirmed terrestrial module efficiencies of crystalline Si solar cells are above $24 \%$ and of multicrystalline $\mathrm{Si}$ solar cells are close to $20 \%$. However, the efficient establishment of solar cell technology on a global scale requires development in terms of materials and device store to reduce the fabrication cost and increase the power conversion efficiency (PCE). As a new entrant in the PV field, organometallic halide perovskites based photovoltaic device offers the advantages of highefficiency, low-cost, and facile solution processability, making it one of the most promising next-generation PV technologies for the future. In perovskite solar cells (PSCs), halide perovskites are of the form $\mathrm{ABX}_{3}$ (A is an organic ammonium ion: $\mathrm{CH}_{3} \mathrm{NH}_{3}^{+}\left(\mathrm{MA}^{+}\right)$or $\mathrm{NH}_{2} \mathrm{CHNH}_{2}^{+}\left(\mathrm{FA}^{+}\right)$, B is $\mathrm{Pb}^{2+}$ or $\mathrm{Sn}^{2+}, \mathrm{X}$ is the halogen ion: $\mathrm{Cl}, \mathrm{Br}$ or I) as the efficient light harvester (Green et al., 2018; Kojima et al., 2009; Burschka et al., 2013; Liu et al., 2013; Yang et al., 2017; Zhao and Zhu, 2016). These perovskite materials possess some fascinating properties, such as tunable bandgap (Noh et al., 2013), high absorption coefficients (Xing et al., 2013), long charge carrier (electron-hole) diffusion length (Stranks et al., 2013), and low-temperature solution processability (Wang et al., 2014). Over the past few years, numerous efforts and extensive investigations have been made into the morphology control of each functional layer (Haque et al., 2017; Yang et al., 2016), compositional engineering of perovskite materials (Hao et al., 2014; Jeon et al., 2015), device structure design (Burschka et al., 2013; Lee et al., 2012; Gao et al., 2014; Cao and Xue, 2014; Tan et al., 2014; Zhang et al., 2017), crystallization modulation of perovskites (Jeon et al., 2014; Xiao et al., 2014; Im et al., 2014) and interfacial engineering (Zhou et al., 2014; 
Zhang et al., 2017; Luo et al., 2017; Assadi et al., 2018). Consequently, the power conversion efficiencies (PCEs) of PSC devices have been boosted from $3.8 \%$ to $22.7 \%$ under 1 sun conditions $\left(100 \mathrm{~mW} \mathrm{~cm}^{-2} \mathrm{AM}\right.$ 1.5G) (Green et al., 2018).

The utilization of highly transparent antireflection coating (ARC) in perovskite solar cells provides an important approach to reduce or suppress Fresnel reflection losses, to increase the amount of light entering the PV device and hence, to enhance the power conversion efficiency of PSCs. PSCs typically are formed on transparent conductive oxide (TCO) glasses, such as fluorine doped tin oxide (FTO) and indium tin oxide (ITO) slides. There is a trade-off in PSC devices between the sheet resistance of the TCO and its optical transmittance. Whilst the use of thicker TCOs can significantly reduce the sheet resistance, it will also result in a decrease in transmittance. Thus, the optical transmittance of FTO or ITO slides is limited, which has a considerable impact the efficiency of PSCs. Currently, the ARCs have been widely employed on silicon ( $\mathrm{Si}$ ) or transparent substrates (e.g., glasses, plastics, etc.) in different types of $\mathrm{Si}$ based or organic solar cells or modules to reduce the surface reflection losses over a broad range of incident wavelengths and angles (Xu et al., 2008; Sakhuja et al., 2014; Raut et al., 2011; Leem et al., 2014a, 2014b; Ballif et al., 2004).

An important and well-known phenomenon lowering the overall PCE of solar cell devices is Fresnel reflection, which takes place when a refractive index contrast exists between the ambient medium (air) and the solar cell device. The reflectance losses due to the refractive index mismatch between a material and the air can be reduced by applying an ARC with an intermediate refractive index between air and the substrate material (Prevo et al., 2005). The antireflection coatings can either be materials with an intermediate refractive index between the substrate and air or porous or refractive index-graded materials (Mahadik et al., 2015). Most of these antireflection coatings (ARCs) are manufactured by film deposition techniques such as chemical vapor deposition (CVD), sputtering, or evaporation, as well as possible lithography steps. These methods are costly and often involve high-temperature environments that are unsuitable for certain solar cell technologies (Wan et al., 2013; Ali et al., 2014; Lopez et al., 2013). Silicon dioxide $\left(\mathrm{SiO}_{2}\right)$ is the most ideal material for ARC due to its low refractive index, good durability and environmental resistance. Especially, $\mathrm{SiO}_{2}$ nanospheres, which do not require vacuum-based or hightemperature fabrication processes, offer a promising nanophotonic ARC option due to their light trapping and scattering properties (Grandidier et al., 2011, 2012). Further, $\mathrm{SiO}_{2}$ nanoscale structures are stable with respect to extreme temperatures and light illumination. Different techniques have been used to achieve layers of $\mathrm{SiO}_{2}$ nanospheres on top of photoactive layers on flexible and rigid substrates, including the Langmuir-Blodgett method (Grandidier et al., 2013; Hsu et al., 2008), sedimentation (Jiang et al., 1999), and controlled evaporation (Mihi et al., 2011). Although these fabrication approaches are simple, scalable and inexpensive and could enable large-scale manufacturability of microresonator-based photovoltaics, the application of nanosphere based ARCs on photovoltaic devices are scarcely reported.

In this study, we demonstrate a facile and simple approach to prepare silica nanosphere based antireflection coatings. $\mathrm{SiO}_{2}$ nanosphere based ARCs were grown by spin-coating of an aged silica sol. The structure and the thickness of the $\mathrm{SiO}_{2}$ nanosphere based ARC were finely adjusted by changing the spin-coating speed from 400 to $4000 \mathrm{rpm}$. The microstructure and the effective refractive index of the $\mathrm{SiO}_{2}$ nanosphere based ARC were optimized to achieve high transmittance. The effect of $\mathrm{SiO}_{2}$ nanosphere based ARCs on the photovoltaic performance of perovskite solar cells is systematically investigated. The optimized $\mathrm{SiO}_{2}$ nanosphere ARC coating on cleaned glass substrate exhibited a maximum transmittance of $96.1 \%$ at $\lambda=550 \mathrm{~nm}$ wavelength, and averagely increased the transmittance by about $3.8 \%$ in a broad wavelength range of $300-800 \mathrm{~nm}$, therefore leading to a significant increase in the efficiency of the PSC device from $14.81 \%$ to $15.82 \%$, demonstrating over $6.8 \%$ enhancement, compared with the reference device without $\mathrm{SiO}_{2}$ nanospheres. The present process provides a simple and cost effective method for the preparation of antireflection coatings, which benefit the development of PSC solar cells, as well as the light-harvesting scheme applicable to a wide variety of optoelectronic devices.

\section{Experimental details}

\subsection{Preparation of the sols and deposition of the thin films}

Tetraethoxysilane (TEOS) was procured from Sigma Aldrich. TEOS was used as a precursor for $\mathrm{SiO}_{2}$ nanosphere ARC coatings. Ethanol also obtained from Sigma Aldrich was used as the solvent $\mathrm{NH}_{3} \cdot 3 \mathrm{H}_{2} \mathrm{O}$ was purchased from Aladdin Industrial Corporation and used for the catalysis of the sol.

A hybrid silica sol was prepared by mixing the precursor materials (Jun et al., 2008). Initially, $1.5 \mathrm{~mL}$ of $\mathrm{NH}_{3} \cdot 3 \mathrm{H}_{2} \mathrm{O}$ solution (10 wt\%) was mixed with deionized (DI) water $(6 \mathrm{~mL})$, ethanol $(70 \mathrm{~mL})$ in a $100 \mathrm{~mL}$ flask by magnetic stirring. Then, $3 \mathrm{~mL}$ of TEOS was added drop by drop to the mixture. The final mixture was magnetically stirred for $30 \mathrm{~min}$. The silica sol obtained was kept at room temperature (RT) for at least 1 day for aging and finally used for deposition on external-facing surfaces of TCO transparent substrates of PSCs.

\subsection{Device fabrication}

FTO slides (Pilkington TEC 15) were patterned by etching with Zn powders and $2 \mathrm{M} \mathrm{HCl}$. The etched slides were then cleaned with liquid detergent, acetone, ethyl alcohol and DI water for $15 \mathrm{~min}$, sequentially, to remove the organic or inorganic residues, and finally dried in a vacuum oven. Titanium isopropoxide (TTIP) $(200 \mu \mathrm{L})$ and ethanol $(5 \mathrm{~mL})$ were mixed to prepare a clear precursor sol. The precursor sol was spincoated onto the etched FTO substrate at $4500 \mathrm{rpm}$, followed by annealing at $500{ }^{\circ} \mathrm{C}$ to form a compact $\mathrm{TiO}_{2}\left(\mathrm{c}-\mathrm{TiO}_{2}\right)$ layer. Diluted $\mathrm{TiO}_{2}$ pastes were prepared by mixing $\mathrm{TiO}_{2}$ paste (Dyesol 18NR-T, $0.1 \mathrm{~g}$ ) and anhydrous ethanol $(444 \mu \mathrm{L})$. The mesoporous $\mathrm{TiO}_{2}\left(\mathrm{p}-\mathrm{TiO}_{2}\right)$ layer was deposited on the $\mathrm{c}-\mathrm{TiO}_{2}$ layer by spin-coating the diluted $\mathrm{TiO}_{2}$ pastes at $2000 \mathrm{rpm}$ for $30 \mathrm{~s}$. The layers were then sintered at $500{ }^{\circ} \mathrm{C}$ for $30 \mathrm{~min}$ in air. After cooling down to the RT, the samples were treated using the $\mathrm{TiCl}_{4}$ aqueous solution at $70^{\circ} \mathrm{C}$ for $30 \mathrm{~min}$ and dried at $500{ }^{\circ} \mathrm{C}$ for $30 \mathrm{~min}$. The perovskite $\mathrm{MAPbI}_{3}$ absorber was grown via a spin-coating process using a GBL/DMSO solution of $\mathrm{PbI}_{2}$ and MAI. Briefly, a pure perovskite-precursor solution $\left(1.25 \mathrm{~mol} \mathrm{~L}^{-1}\right)$ was prepared by mixing MAI $(0.1975 \mathrm{~g})$ powders and lead iodide $\mathrm{PbI}_{2}(0.5785 \mathrm{~g})$ in GBL $(700 \mu \mathrm{L})$ and DMSO $(300 \mu \mathrm{L})$ at $60^{\circ} \mathrm{C}$ for $12 \mathrm{~h}$. The formed precursor solution was deposited onto the $\mathrm{p}-\mathrm{TiO}_{2} / \mathrm{c}-\mathrm{TiO}_{2} / \mathrm{FTO}$ sample via a successive two-step spin-coating process, at $2000 \mathrm{rpm}$ for $30 \mathrm{~s}$ and at $3500 \mathrm{rpm}$ for $50 \mathrm{~s}$, respectively. Anhydrous diethyl ether was dripped onto the center of the sample in the second spin-stage during the spincoating process (Luo et al., 2017). The perovskite-precursor coated sample was heated and dried on a hot plate at $110^{\circ} \mathrm{C}$ for $30 \mathrm{~min}$. The hole-transport material (HTM) was deposited on the grown perovskite absorber by spin-coating a spiro-OMeTAD solution at $4000 \mathrm{rpm}$ for $30 \mathrm{~s}$. $100 \mathrm{~nm}$ thick AgAl alloy film with an active area of $0.1 \mathrm{~cm}^{2}$ was formed via evaporation on the Spiro-OMeTAD-coated film (Jiang et al., 2016). Finally, $\mathrm{SiO}_{2}$ nanosphere based ARCs were deposited on the front glass surface of the as-prepared PSC solar cell by spin-coating of the aged silica sol with various spin-coating speeds from 400 to $4000 \mathrm{rpm}$.

\subsection{Characterization}

The morphologies of $\mathrm{SiO}_{2}$ nanosphere based ARC films were characterized by a high-resolution field emission scanning electron microscope (FESEM, Hitachi S4800). Optical spectra of $\mathrm{SiO}_{2}$ ARCs were examined and characterized by means of ultraviolet-visible light (UV-vis) spectrometer (Hitachi, U-3010). Photocurrent density-voltage $(J-V)$ 

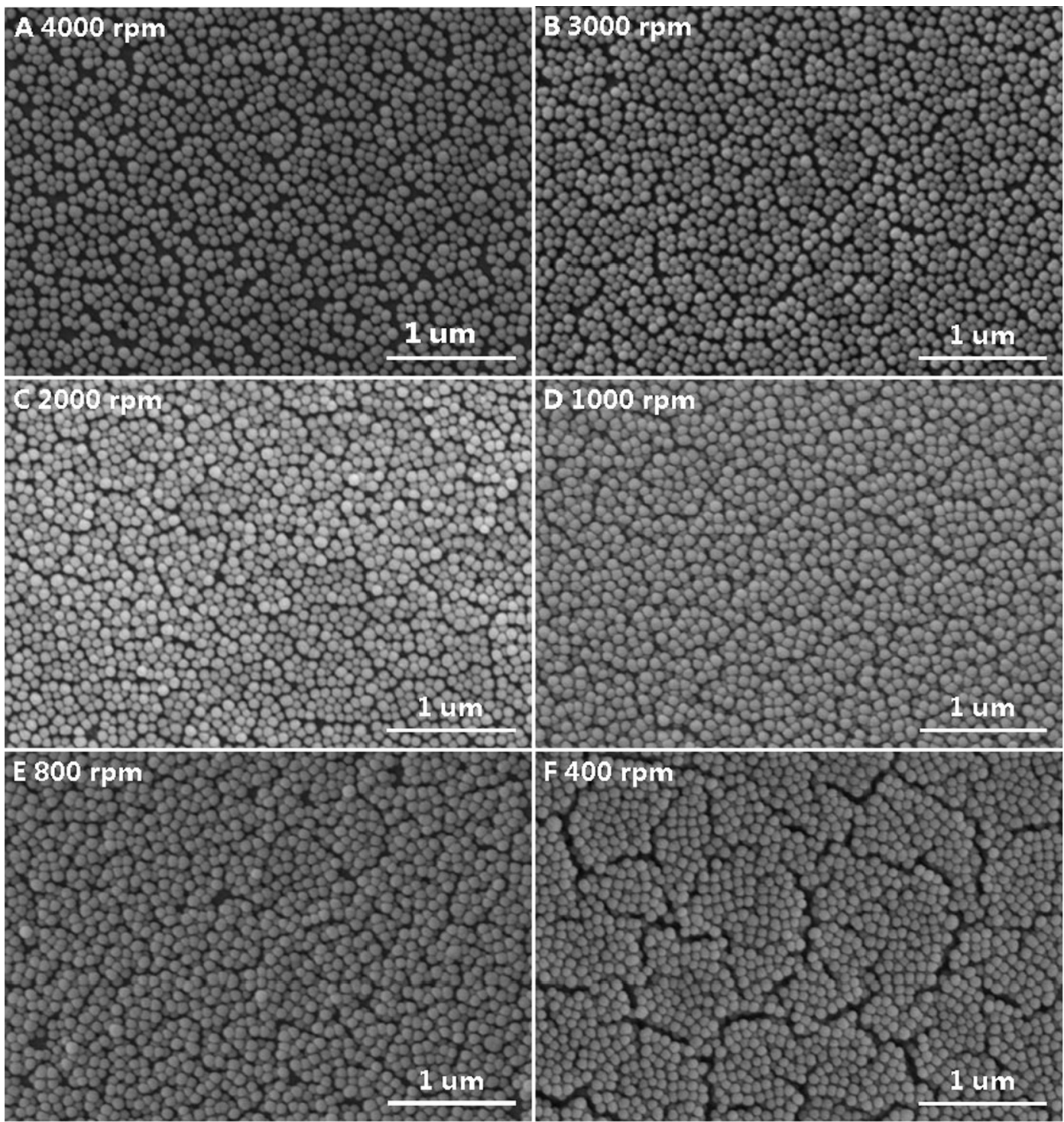

Fig. 1. FESEM image of the top surface morphology of $\mathrm{SiO}_{2}$ sphere based films grown on glass substrates with different spin-coating speeds.

measurements were performed using an AM 1.5 solar simulator equipped with a $1000 \mathrm{~W}$ Xenon lamp (Model No. 91192, Oriel, USA). The solar simulator was calibrated by using a standard silicon cell (Newport, USA). The light intensity was $100 \mathrm{~mW} \mathrm{~cm}^{-2}$ on the surface of the test cell. During device photovoltaic performance characterization, a metal aperture mask with an opening of about $0.09 \mathrm{~cm}^{2}$ was used. External quantum efficiency (EQE) measurements (74125, Oriel, USA) were also carried out for these solar cells.

\section{Results and discussion}

Figs. 1 and 2 show the top surface and cross-sectional SEM images of $\mathrm{SiO}_{2}$ sphere based films grown on glass substrates with different spincoating speeds. From Fig. 1(a), at the spin-coating speed high up to $4000 \mathrm{rpm}$, a monolayer of monodisperse silica spheres was formed on the glass substrate. The synthesis of monodisperse and spherical silica spheres were achieved by the ammonia-catalyzed hydrolysis and condensation of TEOS in mixed ethanol - water solvents (Teng et al., 2010). As can be seen from Figs. 1 and 2, the formed silica spheres have perfect spherical morphology and controllable monodisperse particle size. The size of $\mathrm{SiO}_{2}$ spheres is about $75 \mathrm{~nm}$ in diameter. From the cross-sectional SEM pictures shown in Fig. 2, the spin-coating speed impacted the nanostructure and the thickness of the ARC coating. The sample exhibited increasing film thickness with decreasing spin-coating speed. The top-down SEM micrographs show that, for either monolayer or thicker $\mathrm{SiO}_{2}$ sphere based film, the packing fraction remained relatively uniform, consisting of three-dimensional (3D) close-packed spheres. At the higher speed from $2000 \mathrm{rpm}$ to $4000 \mathrm{rpm}$, the ARC film became submonolayers, with increasing void space between $\mathrm{SiO}_{2}$ spheres, as shown in Fig. 2(a-c). At the lower speed from $800 \mathrm{rpm}$ to $400 \mathrm{rpm}$, the ARC film turned into thicker and more multilayers. At the speed of $400 \mathrm{rpm}$, the number of stacking layers increased to 6. From Figs. 1(d) and 2(d), with a speed of $1000 \mathrm{rpm}$, the ARC film developed into subdouble layers with uniformly distributed voids formed in the upper layer, leading to a 3D crystal architecture, which is more clearly shown in the insert of Fig. 2(d). The surface feature of the $\mathrm{SiO}_{2}$ sphere based ARC deposited at $1000 \mathrm{rpm}$ is similar to that of textured silicon or aluminum-doped zinc oxide surfaces applied in crystalline or amorphous silicon solar cells (Campbell and Green, 1987, 2001; Zhu et al., 2011). A single crystalline Si substrate can be textured by etching along the faces of the crystal planes, leading to a surface made up of random pyramids. Highly efficient crystalline silicon solar cells have been developed using anti-reflection and light trapping properties of pyramidally textured surfaces of $\mathrm{Si}$ wafers. Geometric textures of the $\mathrm{SiO}_{2}$ sphere based ARC deposited at $1000 \mathrm{rpm}$ can in principle perform as well as a random pyramid texture by trapping more light in Si based 

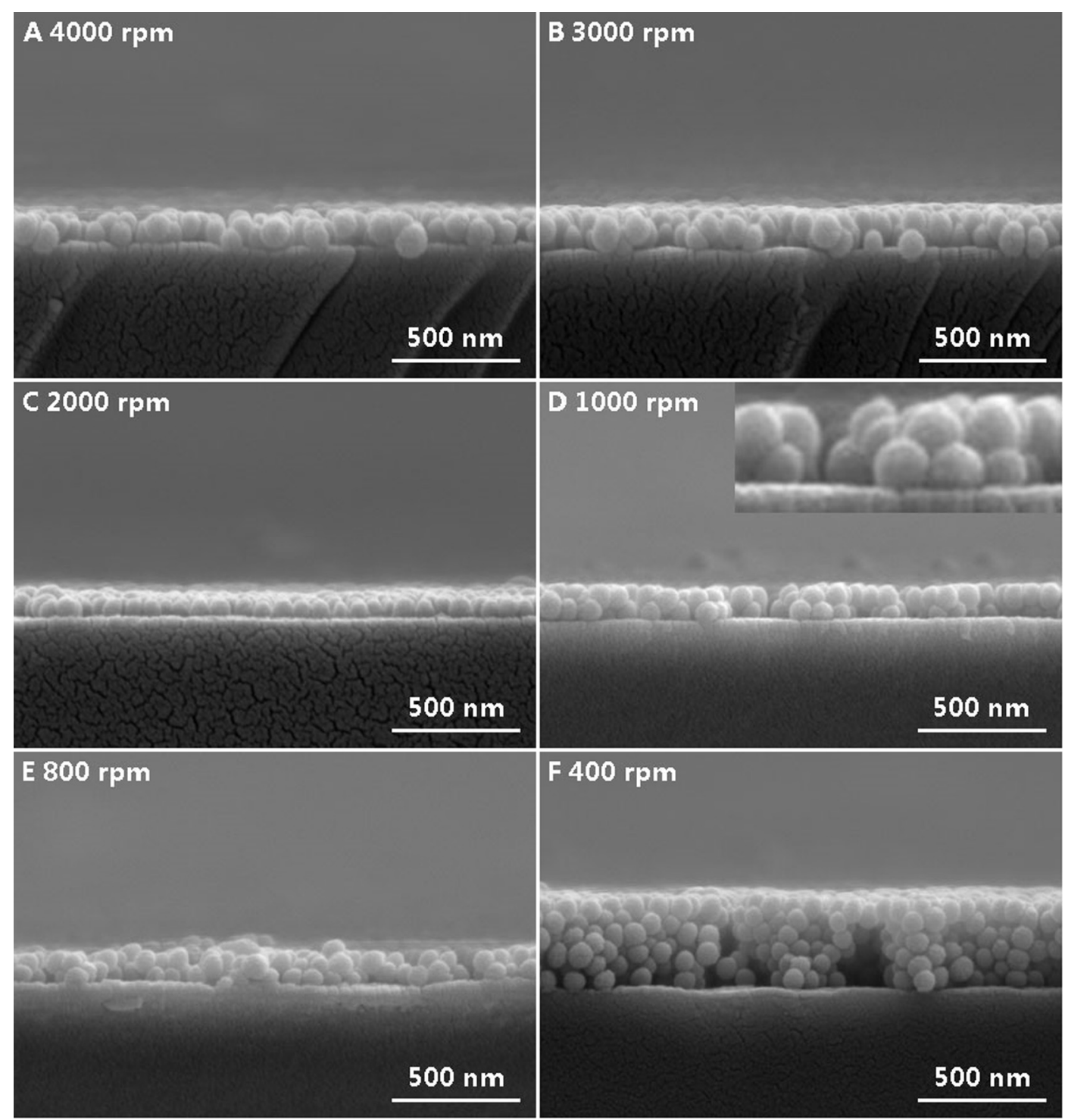

Fig. 2. Cross-sectional FESEM picture of $\mathrm{SiO}_{2}$ sphere based films grown on glass substrates with different spin-coating speeds.

solar cell, with more energetic passing into the PV devices. Using the proposed approach in this work, the particle ARC film thickness and structure could be precisely predictable and controlled. Differently assembled structures of $\mathrm{SiO}_{2}$ nanosphere based ARCs have various optical transmittance properties, and result in different PV performance of PSCs with $\mathrm{SiO}_{2}$ nanosphere based ARCs.

Fig. 3(a) shows the transmittance spectra of the non-coated pristine glass (reference sample) and $\mathrm{SiO}_{2}$ sphere based ARCs grown on glass substrates at different speeds. Their Average $\left(\mathrm{T}_{\text {mean }}\right)$ and maximal $\left(\mathrm{T}_{\max }\right)$ transmittance values in the wavelength region of $400 \mathrm{~nm}-800 \mathrm{~nm}$ are shown in Table 1 . The non-coated pristine glass has an average transmittance $\left(\mathrm{T}_{\text {mean }}\right)$ of $91.5 \%$ in the wavelength region of 400-800 nm. For a low spin-coating speed of $400 \mathrm{rpm}$, the multilayered $\mathrm{SiO}_{2}$ ARC shows a mean transmittance of $90.1 \%$ in this optical region, obviously lower than that of the pristine glass. In contrast, for a speed of $1000-4000 \mathrm{rpm}$, the formed single or double layered $\mathrm{SiO}_{2}$ sphere coating exhibits the higher transmittance than the non-coated pristine glass over the whole UV-visible-near-infrared (NIR) region. For the sample prepared at a speed of $2000-4000 \mathrm{rpm}$, the average transmittance is up to $94 \%-95 \%$. At the sample prepared at a speed of $1000 \mathrm{rpm}$, the average transmittance reaches a maximum value (95.3\%). Thus, the silica coating showed an increased transmitted light of approximately $3.8 \%$ in the wavelength region of $400-800 \mathrm{~nm}$, appropriate for perovskite solar cells.

The transmittance property of an ARC film depends on its thickness and surface morphology. An ideal homogeneous single-layer ARC having an optical thickness of one-quarter of a wavelength achieves effectively $0 \%$ reflection at a specific wavelength when its refractive index, $n_{\mathrm{c}}$, meets the condition of $n_{c}=\sqrt{n_{a} n_{s}}$, where $n_{\mathrm{a}}$ and $n_{\mathrm{s}}$ are the refractive indices of the air and the substrate, respectively (Prevo et al., 2005). The refractive index of soda lime glass is roughly 1.52 at $550 \mathrm{~nm}$, which implies an ideal refractive index of 1.23 for an ARC coating. Moreover, for a single layer coating and normal incidence, according a quarter-wavelength-thick film gives the minimum reflection or maximum transmittance, the wavelength $\lambda$ which corresponds to minimum reflection is calculated by: $\lambda=4 n \times d$, where, $n$ and $d$ represent the refractive index and layer thickness, respectively (Xiao et al., 2014). The refractive index of the $\mathrm{SiO}_{2} \mathrm{AR}$ film is 1.46, therefore the optimum thickness for the wavelength range of $400-800 \mathrm{~nm}$ is 69.0-138.0 nm. The result indicated that the silica sphere ARC films deposited at $1000-4000 \mathrm{rpm}$ were of the proper quarter-wavelength film thickness for AR in the $400-800 \mathrm{~nm}$ wavelength region, considering that the diameter of $\mathrm{SiO}_{2}$ spheres is about $75 \mathrm{~nm}$. Based on the transmittance measurements shown in Fig. 3(a), compared to the case of the reference sample, we further calculate the increase percentage in transmittance $\left(\Delta \mathrm{T} / \mathrm{T}_{\text {ref }}\right)$ with the addition of the $\mathrm{SiO}_{2}$ nanosphere film in 

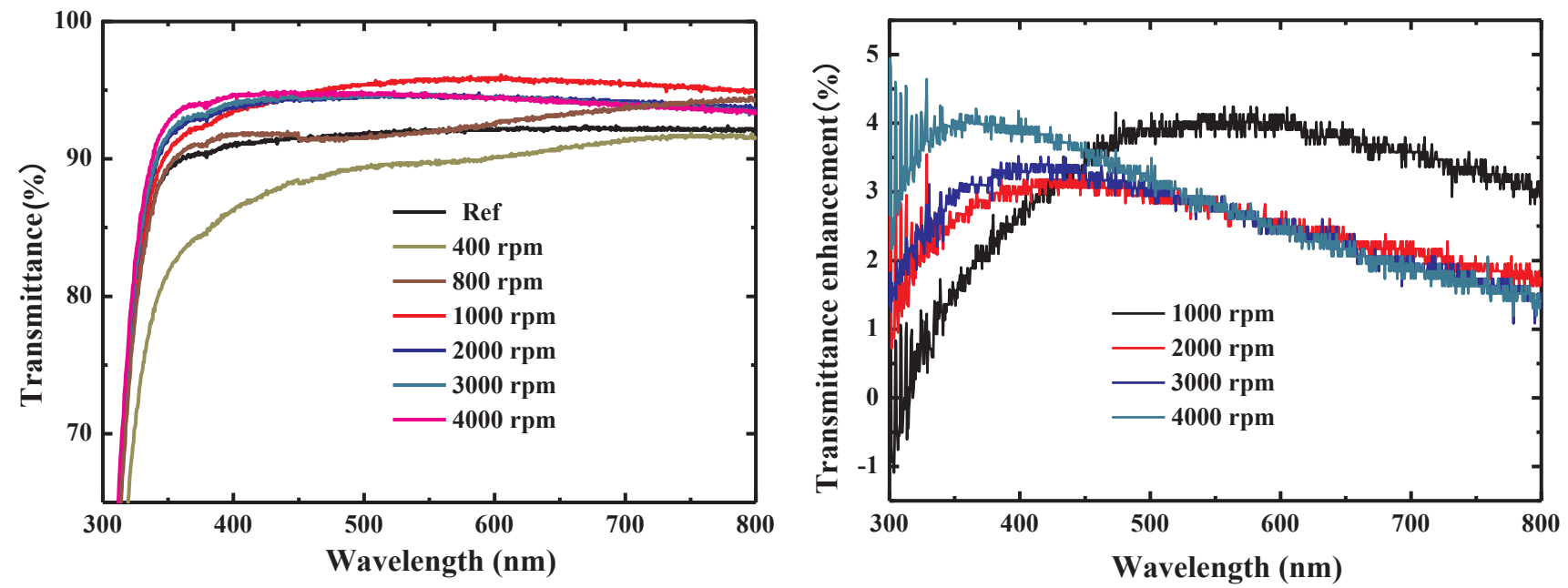

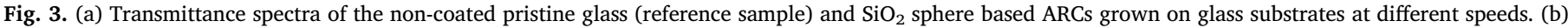
Transmittance enhancements of $\mathrm{SiO}_{2}$ sphere based ARCs grown on glass substrates at speeds of $1000 \mathrm{rpm}-4000 \mathrm{rpm}$.

Table 1

Average $\left(\mathrm{T}_{\text {mean }}\right)$ and maximal $\left(\mathrm{T}_{\max }\right)$ transmittance values of $\mathrm{SiO}_{2}$ sphere based ARCs grown on glass substrates at different speeds in the wavelength region of $400 \mathrm{~nm}-800 \mathrm{~nm}$.

\begin{tabular}{llllllll}
\hline Speed (rpm) & Glass substrate & 4000 & 3000 & 2000 & 1000 & 800 & 400 \\
\hline $\mathrm{T}_{\text {mean }}(\%)$ & 91.5 & 94.3 & 94.3 & 94.2 & 95.3 & 92.7 & 90.1 \\
$\mathrm{~T}_{\max }(\%)$ & 92.4 & 94.9 & 94.8 & 94.8 & 96.1 & 94.5 & 91.9 \\
\hline
\end{tabular}

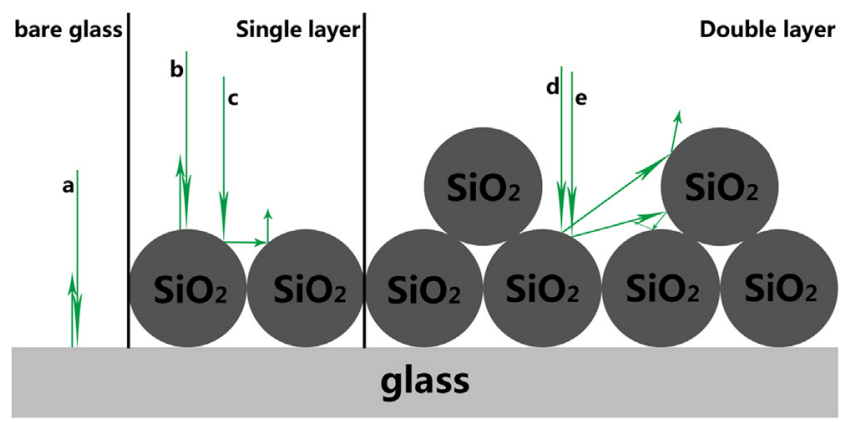

Scheme 1. Schematic of the reflection path of the incident light in the $\mathrm{SiO}_{2}$ sphere based ARCs.

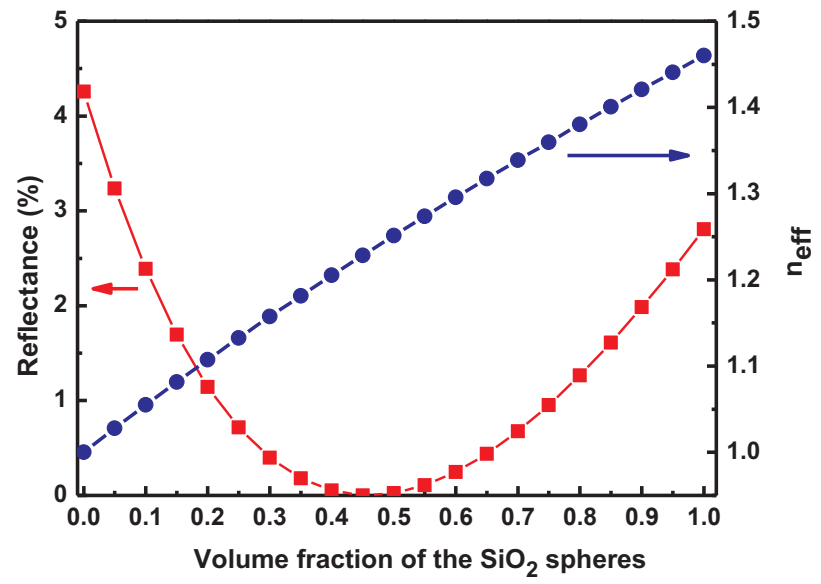

Fig. 4. Calculated reflectance for quarter-wave thickness silica coating on glass using Eq. (2). The effective refractive index neff of the coating from Eq. (1) is plotted on the right axis for reference.
Fig. 3(b). From this figure, the peak of $\Delta \mathrm{T} / \mathrm{T}_{\text {ref }}$ changes with the speed of coating. The maximal transmittance enhancement was achieved at a wavelength of $360 \mathrm{~nm}, 400 \mathrm{~nm}, 405 \mathrm{~nm}$ and $580 \mathrm{~nm}$ for the $\mathrm{SiO}_{2}$ ARC deposited at $4000 \mathrm{rpm}, 3000 \mathrm{rpm}, 2000 \mathrm{rpm}$ and $1000 \mathrm{rpm}$, respectively. Thus, a red-shift of the peak of $\Delta \mathrm{T} / \mathrm{T}_{\text {ref }}$ is observed as the speed slows down. As shown in Fig. 1, the thickness of $\mathrm{SiO}_{2}$ ARC increases as the speed slows down. According to the equation: $\lambda=4 n \times d$, the value of $\lambda$ corresponding to the minimal reflection or the maximal transmittance will increase as the value of $\mathrm{d}$ increase, leading to the red-shift characteristics shown in Fig. 3(b).

A rich variety of optical structures can increase the transmittance property of the film, such as pyramid, inverted pyramid, sub-wavelength grating, nanowire array, biomimetic and so on (Chen and Hong, 2016; Haase and Stiebig, 2007; Esteban et al., 2010; Huang et al., 2012). For a randomly textured surface, the increased transmittance is explained by a second reflection of the incident light at the sidewalls. Different assembly structures of $\mathrm{SiO}_{2}$ ARC films shown in Figs. 1 and 2 lead to different transmittance properties in Fig. 3. As shown in Scheme 1 , for the surface of the bare glass, incident light (light a) reflected just once $\left(\mathrm{T}_{\text {mean }}=91.5 \%\right)$. For the surface of the $\mathrm{SiO}_{2}$ close-packed sphere monolayer ARC, some areas of spheres are almost parallel to the original flat substrate surface, so incident light (light b) also reflected just once, and some areas of spheres have an angle from the original wafer surface, this allows the incident light (light c) to be reflected at least twice on the surface and can reduce the reflection loss $\left(\mathrm{T}_{\text {mean }} \cong 94 \%\right)$. For the surface of the $\mathrm{SiO}_{2}$ sphere multilayer ARC with a close-packed sphere feature, the reflection path of incident light are similar with that for the $\mathrm{SiO}_{2}$ close-packed sphere monolayer, the transmittance would also influenced by the thickness of the film $\left(\mathrm{T}_{\text {mean }}=90 \%-92 \%\right)$. However, for the sub-double layer $\mathrm{SiO}_{2}$ nanosphere based ARC film prepared at $1000 \mathrm{rpm}$, its top surface allows the incident light (light $\mathrm{d}$ and e) to be reflected more times than the case for the single layer $\mathrm{SiO}_{2}$ nanosphere based ARC film, and thus the corresponding reflection loss is much lower $\left(\mathrm{T}_{\text {mean }}=95.3 \%\right)$.

The transmittance property of ARC films prepared with different speeds can also be explained by the changing of volume fraction of the $\mathrm{SiO}_{2}$ nanosphere in the coating. If the ARC coating is a composite made of two or more materials dispersed in sub-wavelength domains, such as a porous thin film of particles tens of nanometers in diameter, the effective refractive index of the nanosphere coating, $n_{\text {eff }}$, can be estimated by a volume average as shown in the following equation (Prevo et al., 2005):

$n_{\text {eff }}=\left(\phi_{\mathrm{p}} n_{\mathrm{p}}^{2}+\left(1-\phi_{\mathrm{p}}\right) \mathrm{n}_{\mathrm{a}}^{2}\right)^{1 / 2}$ 

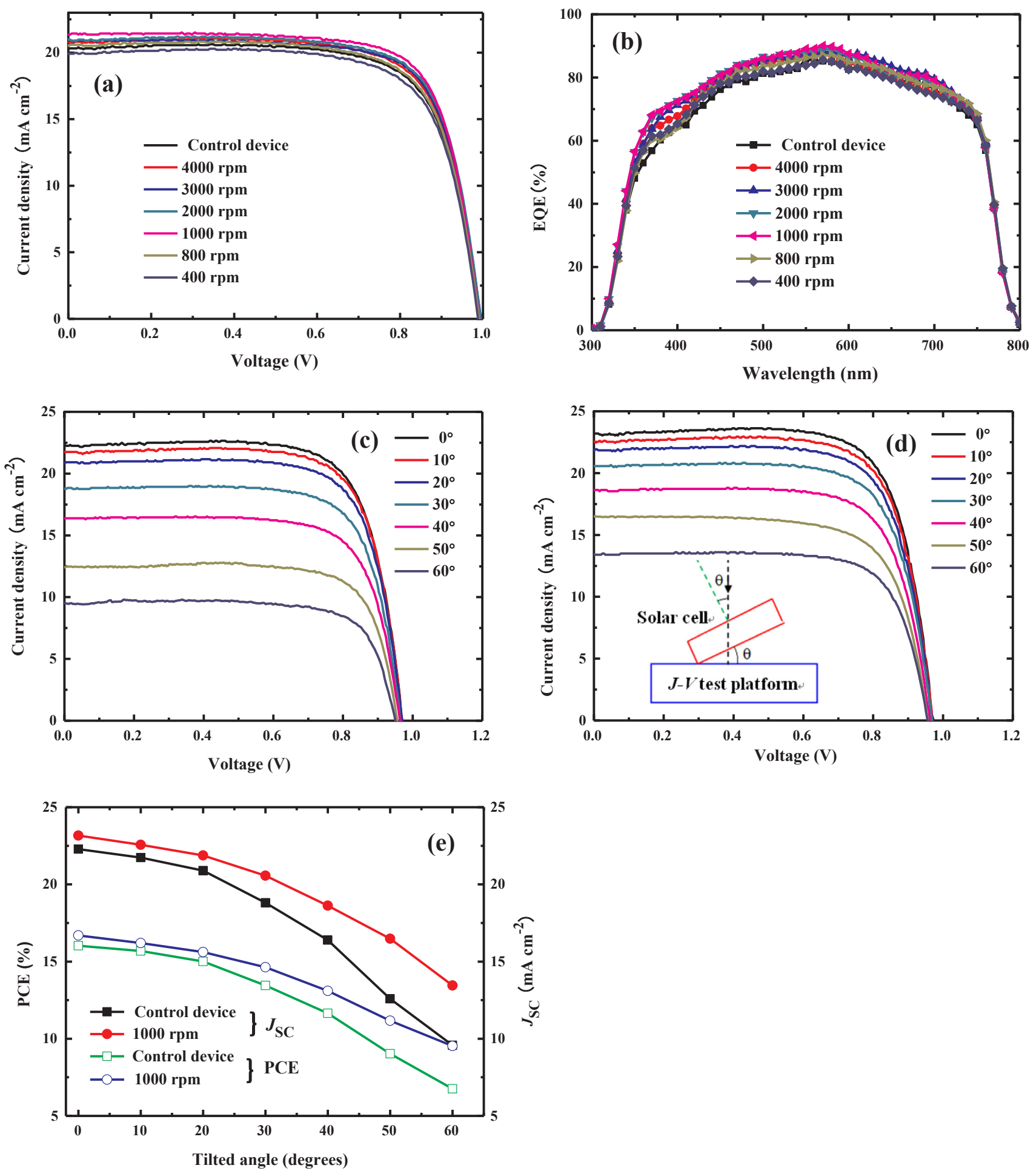

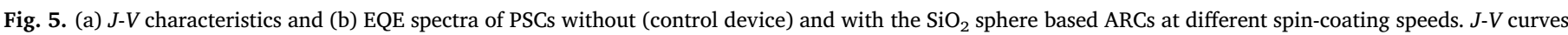

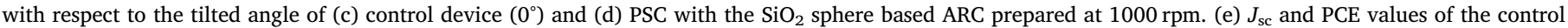
device and the PSC with the $\mathrm{SiO}_{2}$ sphere based ARC prepared at $1000 \mathrm{rpm}$ as function of the tilted angle.

Here $\phi_{\mathrm{p}}$ is the volume fraction of the particles in the coating, while $n_{\mathrm{p}}$ and $n_{\mathrm{a}}$ are the refractive indexes of the particles and the ambient medium (air in this case), respectively. From Eq. (1), $n_{\text {eff }}$ increases monotonically as a function of $\phi_{p}$ from $1.0\left(\mathrm{n}_{\mathrm{a}}\right)$ to $1.46\left(\mathrm{n}_{\mathrm{p}}\right)$, an established value for the refractive index of silica particles. The reflectance $(R)$ can be calculated for quarter-wave thickness silica coating on glass using Eq. (2).

$$
R=\frac{\left(n_{s}-n_{c}^{2}\right)^{2}}{\left(n_{s}+n_{c}^{2}\right)^{2}}
$$

Fig. 4 shows the calculated reflectance for quarter-wave thickness silica coating on glass using Eq. (2). The effective refractive index of the coating from Eq. (1) is plotted on the right axis for reference. As can be seen from Fig. 4, complete ARC at a wavelength of $555 \mathrm{~nm}$ is predicted for $\phi_{\mathrm{p}}=0.45$, which corresponds to $n_{\mathrm{eff}}=1.23$. 
Table 2

Parameters of PSCs without (control device) and with the $\mathrm{SiO}_{2}$ sphere based ARCs at different spin-coating speeds.

\begin{tabular}{lllll}
\hline Device & $V_{\mathrm{OC}}(\mathrm{V})$ & $J_{\mathrm{SC}}\left(\mathrm{mA} / \mathrm{cm}^{2}\right)$ & Fill factor (\%) & Efficiency (\%) \\
\hline Control & 0.99 & 20.34 & 73.5 & 14.81 \\
$4000 \mathrm{rpm}$ & 0.99 & 20.82 & 73.7 & 15.23 \\
$3000 \mathrm{rpm}$ & 0.99 & 20.91 & 74.1 & 15.42 \\
$2000 \mathrm{rpm}$ & 0.99 & 20.97 & 74.5 & 15.51 \\
$1000 \mathrm{rpm}$ & 0.99 & 21.39 & 74.6 & 15.82 \\
$800 \mathrm{rpm}$ & 0.99 & 20.57 & 73.4 & 14.95 \\
$400 \mathrm{rpm}$ & 0.99 & 19.95 & 73.2 & 14.42 \\
\hline
\end{tabular}

Thus, the factor limiting the ARC efficiency of these nanosphere coatings is not the thickness but the coating porosity which dictates the effective refractive index. Our SEM observations clearly exhibit voids distributed throughout the sub-monolayer or the sub-double layer coatings at high deposition speeds of 4000-1000 rpm, as shown in Figs. 1 and 2. The sphere volume fraction volume fraction $\phi_{\mathrm{p}}$ in the ARC coatings extracted from the SEM measurements changed with the spincoating speed. For the sub-monolayer $\mathrm{SiO}_{2}$ nanosphere ARC film deposited at $2000 \mathrm{rpm}, 3000 \mathrm{rpm}$ and $4000 \mathrm{rpm}, \phi_{\mathrm{p}}$ is around 50\%, 41\% and $36 \%$, respectively; hence $\mathrm{n}_{\text {eff }} \sim 1.25,1.21$ and 1.19 , respectively. For the $\mathrm{SiO}_{2}$ nanospheres based ARC film grown at $800 \mathrm{rpm}$ and $1000 \mathrm{rpm}, \phi_{\mathrm{p}}$ is around $51 \%$, and $44 \%$, respectively; hence $\mathrm{n} \sim 1.25$, and 1.22, respectively. For the multilayer $\mathrm{SiO}_{2}$ nanosphere based ARC film at $400 \mathrm{rpm}, \phi_{\mathrm{p}}$ is around $58 \%$; hence $\mathrm{n} \sim 1.29$. The effective refractive index of the $\mathrm{SiO}_{2}$ ARC film deposited at $1000 \mathrm{rpm}$ is closest to 1.23 , where the antireflective coating on the glass substrate achieves effectively $0 \%$ reflection at a wavelength of $550 \mathrm{~nm}$. Therefore, the reflectance, particle packing fraction and effective refractive index data obtained from Eqs. (1) and (2) are consistent with the SEM findings.

The roughening features of the $\mathrm{SiO}_{2}$ sphere based ARC at the suitable speed reduces reflection by increasing the chances of reflected light bouncing back onto the surface or into the PSC device, resulting in the enhanced PV performance of the PSC device, confirmed by the current density-voltage ( $J-V)$ and EQE measurements. Fig. 5(a) and (b) show $J$ - $V$ characteristics and EQE spectra of PSCs without (control device) and with the $\mathrm{SiO}_{2}$ spheres based ARCs at different spin-coating speeds, respectively. The PV parameters obtained from corresponding PSCs including short circuit-current density $\left(J_{\mathrm{SC}}\right)$, open circuit voltage $\left(V_{\mathrm{OC}}\right)$, PCE and fill factor (FF) are tabulated in Table 2. The PV results displayed in Fig. 5 and Table 2 were from the same reference device. The PV performance measurements were first carried out for the asprepared PSC device without $\mathrm{SiO}_{2}$ nanospheres (control device). Then, a $\mathrm{SiO}_{2}$ nanosphere based ARC was deposited on the front glass surface of the control device at a specific spin-coating speed (400-4000 rpm). A blue-green ARC coating was formed on the front glass surface and ready for the PV performance assessments of the PSC device with a $\mathrm{SiO}_{2}$ spheres based ARC. After the PV performance measurements, the $\mathrm{SiO}_{2}$ spheres based ARC was carefully removed from the front glass surface with DI water, ethanol and cotton swabs, and got ready for growth of a new $\mathrm{SiO}_{2}$ nanosphere based ARC at other spin-coating speeds. From Fig. 5(b), in the $400 \mathrm{~nm}-750 \mathrm{~nm}$ range, the EQE value is increased in the order of device@400 rpm < control device < device@ 800 rpm < device@4000 rpm < device@3000 rpm < device@ $2000 \mathrm{rpm}<$ device@1000 rpm. The EQE is a product of light harvesting efficiency, charge separation efficiency, and charge collection efficiency, and hence the EQE improvement is attributed to the improved light harvesting efficiency because the $\mathrm{SiO}_{2}$ sphere ARC film was just attached on the external and front glass surface of the asprepared PSC solar cell without any change with the device inner structure. From Fig. 5(a) and Table 2, the reference device exhibits a $V_{\mathrm{OC}}$ of $0.99 \mathrm{~V}, J_{\mathrm{SC}}$ of $20.34 \mathrm{~mA} \mathrm{~cm}^{-2}$ and $\mathrm{FF}$ of $73.5 \%$, resulting in a total PCE of $14.81 \%$. The increased trend of the $J_{\mathrm{SC}}$ and the PCE values in the PSC device with respect to the $\mathrm{SiO}_{2}$ nanosphere based ARC is consistent with the EQE findings. The improved device efficiency can be attributed to the improved $J_{\mathrm{SC}}$ due to the increased transmittance by the AR function of the $\mathrm{SiO}_{2}$ sphere based ARC film shown in Fig. 3. The optimal cell was obtained with the $\mathrm{SiO}_{2}$ nanosphere based ARC film deposited at $1000 \mathrm{rpm}$. It shows a PCE of $15.82 \%$, demonstrating over $6.8 \%$ enhancement, compared with the reference device without $\mathrm{SiO}_{2}$ nanospheres. The PCE enhancement for the device@1000 rpm comes from the greatly improved short-circuit photocurrent $J_{\mathrm{SC}}$ (from 20.34 to $21.39 \mathrm{~mA} \mathrm{~cm}^{-2}$ ). The $\mathrm{J}-\mathrm{V}$ characteristics and $\mathrm{EQE}$ results are supported by the optical measurement data shown in Fig. 3.

Fig. 5(c) and (d) show the $J$ - $V$ curves with different tilted angles for the control device and the PSC with the $\mathrm{SiO}_{2}$ sphere based ARC prepared at $1000 \mathrm{rpm}$, respectively. During the measurements, the AM 1.5 solar light vertically irradiated on the $J$ - $V$ test platform, and the PSC device was placed on the platform with various tilted angles $\left(\theta=0^{\circ}-60^{\circ}\right)$ above the horizontal during $J$ - $V$ characterization as shown in the insert of Fig. 5(d). The incident angle of solar light at the surface of the measured solar cell is equal to the tilted angle. As we observed, both $J_{\mathrm{SC}}$ and PCE values of the PSC with the optimized $\mathrm{SiO}_{2}$ sphere based ARC smoothly decreased with respect to the tilted angle of the device, whereas those of the reference device more steeply and quickly decreased with the increase of the tilted angle. This trend can be seen more clearly in Fig. 5(e), where we have plotted the $J_{\mathrm{SC}}$ and PCE data as function of the tilted angle. The result might be attributed to the enhanced light absorption in the active layer of the device due to the increased effective optical path lengths (i.e., strong light scattering) caused by the $\mathrm{SiO}_{2}$ sphere based ARC film. Furthermore, the omnidirectionally aligned microstructures of the optimized $\mathrm{SiO}_{2}$ sphere based ARC allow for suppressing the surface reflection for obliquely incident light (Leem et al., 2013). Therefore, the PSC device with the optimized $\mathrm{SiO}_{2}$ sphere based ARC can generate electricity more efficiently under the circumstance of varying the incident angle of light in a day and the seasons than the reference device. The $\mathrm{SiO}_{2}$ nanosphere based ARC prepared at $1000 \mathrm{rpm}$ strongly suppress broadband and wide-angle reflectance in typical PSC solar cells, significantly enhancing the omnidirectional PV performance of PSCs.

\section{Conclusions}

We have developed silica dielectric nanosphere ARCs that suppress broadband and wide-angle reflectance within $\mathrm{CH}_{3} \mathrm{NH}_{3} \mathrm{PbI}_{3} \mathrm{PSC}$ devices and ultimately increase the power conversion efficiency and enhance the omnidirectional photovoltaic performance of solar cells. $\mathrm{SiO}_{2}$ nanosphere based ARCs were grown by spin-coating of an aged silica sol. The microstructure and the thickness of the $\mathrm{SiO}_{2}$ nanosphere based ARC were controlled by changing the spin-coating speed from 400 to $4000 \mathrm{rpm}$. The optimized $\mathrm{SiO}_{2}$ nanosphere ARC coating on cleaned glass substrate exhibited a maximum transmittance of $96.1 \%$ at $\lambda=550 \mathrm{~nm}$ wavelength, and averagely increased the transmittance by about $3.8 \%$ in a broadband of $400-800 \mathrm{~nm}$. The power conversion efficiency was improved from $14.81 \%$ for reference device without $\mathrm{SiO}_{2}$ nanospheres to $15.82 \%$ for the PSC device with the optimized ARC. Also, the PV performance of the PSC device with the optimized $\mathrm{SiO}_{2}$ nanosphere ARC revealed less angular dependence for incident light. Because the layer of $\mathrm{SiO}_{2}$ nanospheres can be grown with an easy, inexpensive, and scalable process, this type of ARC is an excellent candidate for replacing conventional ARC technologies that are inappropriate for certain photovoltaic technologies.

\section{Acknowledgements}

This work was supported by Natural Science Foundation of Shanghai (Nos. 18ZR1411900 and 18ZR1411000) and National Natural Science Foundation of China (Nos. 11274119 and 61275038). Z. B. Wang thanks funding support from the 2nd Solar Photovoltaic Academic Research Consortium (SPARC II), the European Regional 


\section{Development Fund (ERDF) and the Welsh European Funding Office (WEFO).}

\section{References}

Kerr, R.A., 2007. Global warming: how urgent is climate change? Science 318, 1230-1231.

Green, Martin A., Hishikawa, Y., Dunlop, E.D., Levi, D.H., Hohl-Ebinger, J., Ho-Baillie, A.W.Y., 2018. Solar cell efficiency tables (version 51). Prog. Photovolt. Res. Appl. 26, 3-12.

Kojima, A., Teshima, K., Shirai, Y., Miyasaka, T., 2009. Organometal halide perovskites as visible-light sensitizers for photovoltaic cells. J. Am. Chem. Soc. 131, 6050-6051.

Burschka, J., Pellet, N., Moon, S.J., Humphry-Baker, R., Gao, P., Nazeeruddin, M.K. Gratzel, M., 2013. Sequential deposition as a route to high-performance perovskitesensitized solar cells. Nature 499, 316-319.

Liu, M., Johnston, M.B., Snaith, H.J., 2013. Efficient planar heterojunction perovskite solar cells by vapour deposition. Nature 501, 395-398.

Yang, W.S., Park, B.W., Jung, E.H., Jeon, N.J., Kim, Y.C., Lee, D.U., Shin, S.S., Seo, J., Kim, E.K., Noh, J.H., Seok, S.I., 2017. Iodide management in formamidinium-leadhalide-based perovskite layers for efficient solar cells. Science 356, 1376-1379.

Zhao, Y., Zhu, K., 2016. Organic-inorganic hybrid lead halide perovskites for optoelectronic and electronic applications. Chem. Soc. Rev. 45, 655-689.

Noh, J.H., Im, S.H., Heo, J.H., Mandal, T.N., Seok, S.I., 2013. Chemical management for colorful, efficient, and stable inorganic-organic hybrid nanostructured solar cells. Nano. Lett. 13, 1764-1769.

Xing, G.C., Mathews, N., Sun, S.Y., Lim, S.S., Lam, Y.M., Gratzel, M., Mhaisalkar, S., Sum, T.C., 2013. Long-range balanced electron- and hole-transport lengths in organic-inorganic $\mathrm{CH}_{3} \mathrm{NH}_{3} \mathrm{PbI}_{3}$. Science 342, 344-347.

Stranks, S.D., Eperon, G.E., Grancini, G., Menelaou, C., Alcocer, M.J.P., Leijtens, T., Herz, L.M., Petrozza, A., Snaith, H.J., 2013. Electron-hole diffusion lengths exceeding 1 micrometer in an organometal trihalide perovskite absorber. Science 342, 341-344.

Wang, J.T., Ball, J.M., Barea, E.M., Abate, A., Alexander-Webber, J.A., Huang, J., Saliba, M., Mora-Sero, I., Bisquert, J., Snaith, H.J., Nicholas, R.J., 2014. Low-temperature processed electron collection layers of graphene/ $\mathrm{TiO}_{2}$ nanocomposites in thin film perovskite solar cells. Nano. Lett. 14, 724-730.

Haque, M.A., Sheikh, A.D., Guan, X., Wu, T., 2017. Metal oxides as efficient charge transporters in perovskite solar cells. Adv. Energy Mater. 7, 1602803.

Yang, G., Tao, H., Qin, P., Ke, W., Fang, G., 2016. Recent progress in electron transport layers for efficient perovskite solar cells. J. Mater. Chem. A 4, 3970-3990.

Hao, F., Stoumpos, C.C., Cao, D.H., Chang, R.P.H., Kanatzidis, M.G., 2014. Lead-free solid-state organic-inorganic halide perovskite solar cells. Nat. Photonics 8, 489-494.

Jeon, N.J., Noh, J.H., Yang, W.S., Kim, Y.C., Ryu, S., Seo, J., Seok, S.I., 2015. Compositional engineering of perovskite materials for high-performance solar cells. Nature 517, 476-480.

Lee, M.M., Teuscher, J., Miyasaka, T., Murakami, T.N., Snaith, H.J., 2012. Efficient hybrid solar cells based on meso-superstructured organometal halide perovskites. Science 338, 643-647.

Gao, X., Li, J., Baker, J., Hou, Y., Guan, D., Chen, J., Yuan, C., 2014. Enhanced photovoltaic performance of perovskite $\mathrm{CH}_{3} \mathrm{NH}_{3} \mathrm{PbI}_{3}$ solar cells with freestanding $\mathrm{TiO}_{2}$ nanotube array films. Chem. Commun. 50, 6368-6371.

Cao, W., Xue, J., 2014. Recent progress in organic photovoltaics: device architecture and optical design. Energy Environ. Sci. 7, 2123-2144.

Tan, K.W., Moore, D.T., Saliba, M., Sai, H., Estroff, L.A., Hanrath, T., Snaith, H.J., Wiesner, U., 2014. Thermally induced structural evolution and performance of mesoporous block copolymer-directed alumina perovskite solar cells. ACS Nano 8, 4730-4739.

Zhang, Y., Zhang, Z., Yan, W., Zhang, B., Feng, Y., Asiri, A.M., Nazeeruddin, M.K., Gao, P., 2017. Hexagonal mesoporous silica islands to enhance photovoltaic performance of planar junction perovskite solar cells. J. Mater. Chem. A 5, 1415-1420.

Jeon, N.J., Noh, J.H., Kim, Y.C., Yang, W.S., Ryu, S., Seok, S.I., 2014. Solvent engineering for high-performance inorganic-organic hybrid perovskite solar cells. Nat. Mater. 13, 897-903.

Xiao, M., Huang, F., Huang, W., Dkhissi, Y., Zhu, Y., Etheridge, J., Gray-Weale, A., Bach, U., Cheng, Y.B., Spiccia, L., 2014. A fast deposition-crystallization procedure for highly efficient lead iodide perovskite thin-film solar cells. Angew Chem. Int. Ed. Engl. 53, 9898-9903.

Im, J.H., Jang, I.H., Pellet, N., Gratzel, M., Park, N.G., 2014. Growth of $\mathrm{CH}_{3} \mathrm{NH}_{3} \mathrm{PbI}_{3}$ cuboids with controlled size for high-efficiency perovskite solar cells. Nat. Nanotechnol. 9, 927-932.

Zhou, H.P., Chen, Q., Li, G., Luo, S., Song, T.B., Duan, H.S., Hong, Z.R., You, J.B., Liu, Y.S., Yang, Y., 2014. Interface engineering of highly efficient perovskite solar cells. Science 345, 542-546.

Zhang, C., Luo, Q., Deng, X., Zheng, J., Ou-Yang, W., Chen, X., Huang, S., 2017. Enhanced efficiency and stability of carbon based perovskite solar cells using terephthalic acid additive. Electrochim. Acta 258, 1262-1272.

Luo, Q., Zhang, C., Deng, X., Zhu, H., Li, Z., Wang, Z., Chen, X., Huang, S., 2017. Plasmonic effects of metallic nanoparticles on enhancing performance of perovskite solar cells. ACS Appl. Mater. Interfaces 9, 34821-34832.

Assadi, M.K., Bakhoda, S., Saidur, R., Hanaei, H., 2018. Recent progress in perovskite solar cells. Renew. Sust. Energ. Rev. 81, 2812-2822.

Xu, H., Lu, N., Qi, D., Hao, J., Gao, L., Zhang, B., Chi, L., 2008. Biomimetic antireflective Si nanopillar arrays. Small 4, 1972-1975.

Sakhuja, M., Son, J., Verma, L.K., Yang, H., Bhatia, C.S., Danner, A.J., 2014. Omnidirectional study of nanostructured glass packaging for solar modules. Prog. Photovolt 22, 356-361.

Raut, H.K., Ganesh, V.A., Nair, A.S., Ramakrishna, S., 2011. Anti-reflective coatings: a critical, in-depth review. Energ. Environ. Sci. 4, 3779.

Leem, J.W., Kim, S., Lee, S.H., Rogers, J.A., Kim, E., Yu, J.S., 2014a. Efficiency enhancement of organic solar cells using hydrophobic antireflective inverted moth-eye nanopatterned PDMS films. Adv. Energy Mater. 4, 1301315.

Ballif, C., Dicker, J., Borchert, D., Hofmann, T., 2004. Solar glass with industrial porous $\mathrm{SiO}_{2}$ antireflection coating: measurements of photovoltaic module properties improvement and modelling of yearly energy yield gain. Sol. Energy Mater. Sol. Cells $82,331-344$.

Leem, J.W., Yu, J.S., Heo, J., Park, W.K., Park, J.H., Cho, W.J., Kim, D.E., 2014b. Nanostructured encapsulation coverglasses with wide-angle broadband antireflection and self-cleaning properties for III-V multi-junction solar cell applications. Sol. Energy Mater. Sol. Cells 120, 555-560.

Prevo, B.G., Hwang, Y., Velev, O.D., 2005. Convective assembly of antireflective silica coatings with controlled thickness and refractive index. Chem. Mater. 17, 3642-3651.

Mahadik, D.B., Lakshmi, R.V., Barshilia, H.C., 2015. High performance single layer nanoporous antireflection coatings on glass by sol-gel process for solar energy applications. Sol. Energy Mater. Sol. Cells 140, 61-68.

Wan, Y., McIntosh, K.R., Thomson, A.F., 2013. Characterisation and optimisation of PECVD SiNx as an antireflection coating and passivation layer for silicon solar cells. AIP Adv. 3, 032113.

Ali, K., Khan, S.A., Jafri, M.Z.M., 2014. Effect of double layer $\left(\mathrm{SiO}_{2} / \mathrm{TiO}_{2}\right)$ anti-reflective coating on silicon solar cells. Int. J. Electrochem. Sci. 9, 7865-7874.

Lopez, G., Ortega, P.R., Voz, C., Martin, I., Colina, M., Morales, A.B., Orpella, A., Alcubilla, R., 2013. Surface passivation and optical characterization of $\mathrm{Al}_{2} \mathrm{O}_{3} / \mathrm{a}-\mathrm{SiC}_{\mathrm{x}}$ stacks on c-Si substrates. Beilstein J. Nanotechnol. 4, 726-731.

Grandidier, J., Callahan, D.M., Munday, J.N., Atwater, H.A., 2011. Light absorption enhancement in thin-film solar cells using whispering gallery modes in dielectric nanospheres. Adv. Mater. 23, 1272-1276.

Grandidier, J., Callahan, D.M., Munday, J.N., Atwater, H.A., 2012. Gallium arsenide solar cell absorption enhancement using whispering gallery modes of dielectric nanospheres. IEEE J. Photovolt. 2, 123-128.

Grandidier, J., Weitekamp, R.A., Deceglie, M.G., Callahan, D.M., Battaglia, C., Bukowsky, C.R., Ballif, C., Grubbs, R.H., Atwater, H.A., 2013. Solar cell efficiency enhancement via light trapping in printable resonant dielectric nanosphere arrays. Phys. Status Solidi A 210, 255-260.

Hsu, C.-M., Connor, S.T., Tang, M.X., Cui, Y., 2008. Wafer-scale silicon nanopillars and nanocones by Langmuir-Blodgett assembly and etching. Appl. Phys. Lett. 93, 133109.

Jiang, P., Bertone, J.F., Hwang, K.S., Colvin, V.L., 1999. Single-crystal colloidal multilayers of controlled thickness. Chem. Mater. 11, 2132-2140.

Mihi, A., Zhang, C., Braun, P.V., 2011. Transfer of preformed three-dimensional photonic crystals onto dye-sensitized solar cells. Angew. Chem. Int. Ed. Engl. 50, 5712-5715.

Jun, S., Me, Z.Y., Wu, X.X., Ling, O.Y., Xiao, Y.Q., 2008. Sol-gel derived $\mathrm{SiO}_{2}$ antireflective (AR) coating used in solar cells. Rare Metal Mat. Eng. 37, 47-50.

Jiang, Z., Chen, X., Lin, X., Jia, X., Wang, J., Pan, L., Huang, S., Zhu, F., Sun, Z., 2016. Amazing stable open-circuit voltage in perovskite solar cells using AgAl alloy electrode. Sol. Energy Mater. Sol. Cells 146, 35-43.

Teng, Z., Han, Y., Li, J., Yan, F., Yang, W., 2010. Preparation of hollow mesoporous silica spheres by a sol-gel/emulsion approach. Micropor. Mesopor. Mat. 127, 67-72.

Campbell, P., Green, M.A., 1987. Light trapping properties of pyramidally textured surfaces. J. Appl. Phys. 62, 243-249.

Campbell, P., Green, M.A., 2001. High performance light trapping textures for monocrystalline silicon solar cells. Sol. Energy Mater. Sol. Cells 65, 369-375.

Zhu, H., Hüpkes, J., Bunte, E., Owen, J., Huang, S.M., 2011. Novel etching method on high rate $\mathrm{ZnO}$ : Al thin films reactively sputtered from dual tube metallic targets for silicon-based solar cells. Sol. Energy Mater. Sol. Cells 95, 964-968.

Chen, W.-H., Hong, F.C.-N., 2016. 0.76\% absolute efficiency increase for screen-printed multicrystalline silicon solar cells with nanostructures by reactive ion etching. Sol. Energy Mater. Sol. Cells 157, 48-54.

Haase, C., Stiebig, H., 2007. Thin-film silicon solar cells with efficient periodic light trapping texture. Appl. Phys. Lett. 91, 061116.

Esteban, R., Laroche, M., Greffet, J.J., 2010. Dielectric gratings for wide-angle, broadband absorption by thin film photovoltaic cells. Appl. Phys. Lett. 97, 221111.

Huang, B.-R., Yang, Y.-K., Lin, T.-C., Yang, W.-L., 2012. A simple and low-cost technique for silicon nanowire arrays based solar cells. Sol. Energy Mater. Sol. Cells 98, 357-362.

Leem, J.W., Song, Y.M., Yu, J.S., 2013. Biomimetic artificial Si compound eye surface structures with broadband and wide-angle antireflection properties for Si-based optoelectronic applications. Nanoscale 5, 10455-10460. 